\title{
NMR ANALYS
}


GULDET

Rapporten handlar om social tillit i de nordiska samhällena. Norden har högst nivåer av social tillit i världen. Detta gynnar såväl samhällsekonomin som individer och samhället i dess helhet. Rapporten diskuterar bakgrunden till att den sociala tilliten blivit så hög i Norden samt vilka utmaningar som den står inför.

(II) Nordiska ministerrådet 
Tillit - det nordiska guldet

Ulf Andreasson

ANP 2017:731

ISBN 978-92-893-5003-7 (PRINT)

ISBN 978-92-893-5004-4 (PDF)

ISBN 978-92-893-5005-1 (EPUB)

http://dx.doi.org/10.6027/ANP2017-731

(c) Nordiska ministerrådet 2017

Layout: Mette Agger Tang

Tryck: Rosendahls

Printed in Denmark

\section{Det nordiska samarbetet}

Det nordiska samarbetet är ett av världens mest omfattande regionala samarbeten. Det omfattar Danmark, Finland, Island, Norge och Sverige samt Färöarna, Grönland och Åland.

Det nordiska samarbetet är politiskt, ekonomiskt och kulturellt förankrat och en viktig del av europeiskt och internationellt samarbete. Den nordiska gemenskapen arbetar för ett starkt Norden i ett starkt Europa.

Det nordiska samarbetet vill styrka nordiska och regionala intressen och värderingar i en global omvärld. Gemensamma värderingar länderna emellan bidrar till att stärka Nordens ställning som en av världens mest innovativa och konkurrenskraftiga regioner.

\section{Nordiska ministerrådet \\ Ved Stranden 18 \\ DK-1061 København K \\ www.norden.org}

Ladda ner nordiska publikationer: www.norden.org/nordpub 


$$
\begin{aligned}
& \text { TILLIT - } \\
& \text { DET NORDISKA } \\
& \text { GULDET }
\end{aligned}
$$




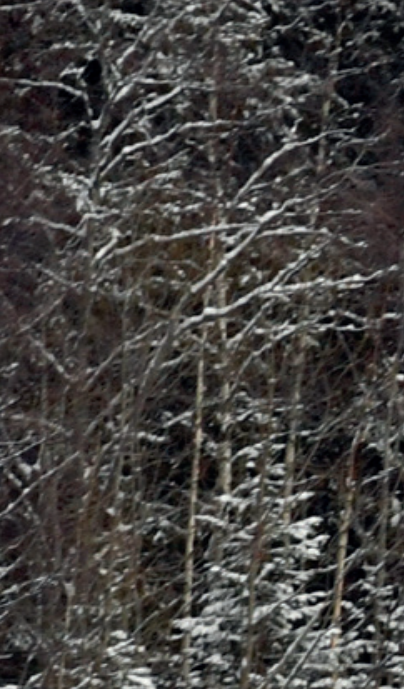

2.




3.5.



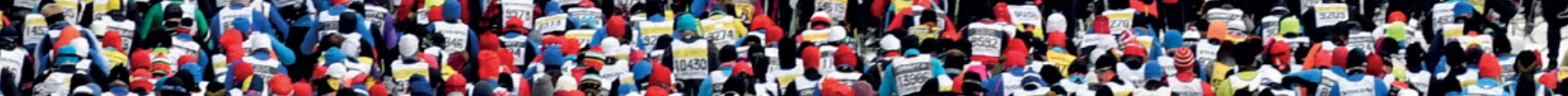

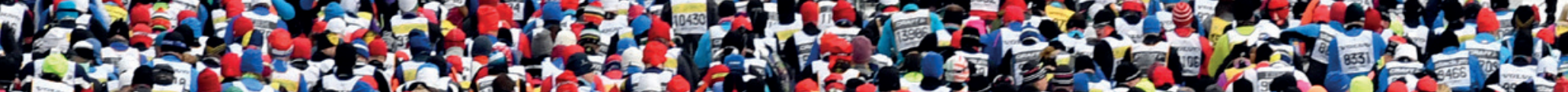
1.5.

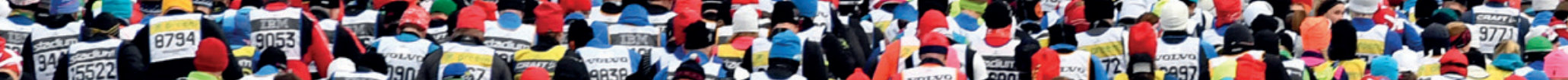

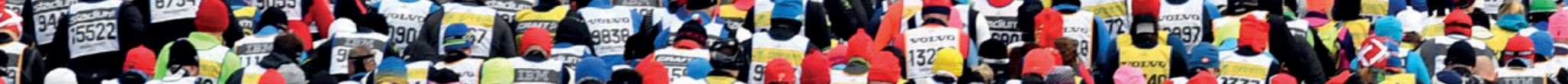

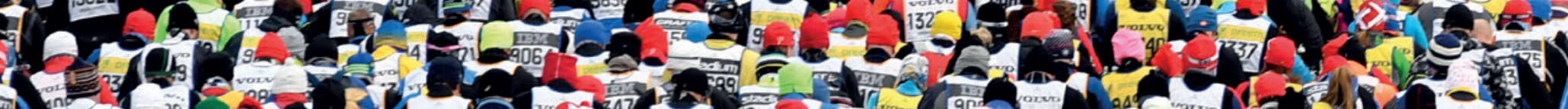
(1)

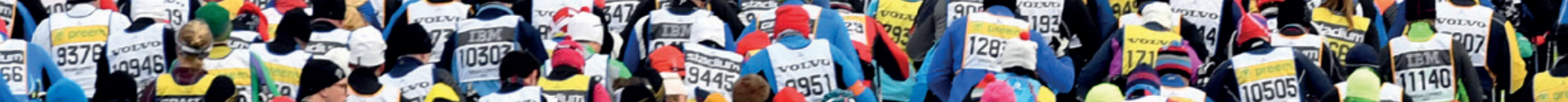






\section{Innehåll}

7 Förord

8 Sammanfattning

10 Inledning

11 Välsignelser av tillit

13 Den nordiska tilliten

14 Tillit så in i Norden

18 Utmaningar för den nordiska tilliten

20 Konklusioner

22 Referenser 


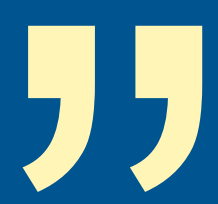

Det är svårt att föreställa sig samhällsmodeller som de nordiska om inte medborgarna litar på att andra medborgare också genom skattesystemet bidrar till samhällsekonomin samt att myndigheterna hanterar medlen på ett rättvist och effektivt sätt fritt från korruption. 


\section{Förord}

Föreliggande rapport handlar om tillit, eller mer specifikt om social tillit. Ämnet har lockat till åtskillig forskning under de senaste årtiondena. Det är också ett ämne som i allra högsta grad har en nordisk botten. Som region betraktat är Norden världsmästare vad det gäller social tillit i befolkningen. Den omfattande forskningslitteraturen på området menar att hög social tillit är kanske den enskilt viktigaste resurs ett samhälle kan ha. Därför kan man, som titeln på rapporten indikerar, betrakta tilliten som ett slags guld för de nordiska länderna.

Rapporten ger en bakgrundsbild till hur Norden lyckats få så höga tillitsnivåer. Kortfattat är det resultatet av flera samhälleliga processer, varav några sträcker sig långt tillbaka i historien medan andra är mer nutida. I denna text ligger fokus på föreningslivets historiska roll i de nordiska samhällena samt statens funktion. Vad gäller statens funktion är frånvaron av korruption, välfungerande och rättvisa samhällsinstitutioner samt en generell välfärdsstat aspekter som haft central relevans för tilliten. En särskild dimension som berörs i rapporten gäller kopplingen mellan föreningslivet och staten - vilket varit extra viktig i en nordisk kontext.

I rapporten förs också en diskussion om vilka utmaningar som den sociala tilliten i Norden står inför. Även om det finns flera tuffa utmaningar kan man konstatera att frågan om framtiden för den sociala tilliten i samhället inte är ödesbestämd utan på många sätt ligger i politikers och andra beslutsfattares händer.

Rapporten är författad av Ulf Andreasson vid Nordiska Ministerrådets analysoch utredningsenhet. Tanken är att inom ramen för rapportserien belysa aktuella ämnen som är centrala utifrån ett nordiskt perspektiv.

Köpenhamn, april 2017

\section{Dagfinn Høybråten}

Generalsekreterare

Nordiska ministerrådet 


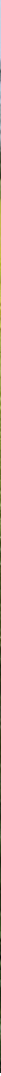

\section{Sammanfattning}

All tillgänglig forskning menar att de nordiska samhällena kännetecknas av höga nivåer av social tillit. Nivåerna är inte bara höga i sig, de särskiljer Danmark, Finland, Island, Norge och Sverige från resten av världen: inga andra länder kommer upp i samma nivåer.

Samhällsekonomin gynnas på flera sätt av hög social tillit. Ett samhälle med hög social tillit präglas i mindre grad av formaliteter, konflikter och rättsprocesser. I ekonomiska termer talar man särskilt om att social tillit minskar transaktionskostnader i ekonomin, alltså kostnader förbundna med att försäkra sig om att avtal efterlevs. Beräkningar tyder på att en ökning av den sociala tilliten med tio procentenheter kan förväntas ge en halv procentenhets ökning av den ekonomiska tillväxten i ett land. Effekterna av tillit sträcker sig bortanför rent ekonomiska aspekter. Forskningen har vidare konstaterat effekter av social tillit vid sidan om de samhällsekonomiska. Över lag är människor med hög grad av tillit mer benägna att uppfatta att de har större kontroll över sina liv och bättre livschanser. Tillit har också kommit att betraktas som en viktig beståndsdel i främjandet av engagemang i samhället i stort samtidigt som den reducerar kriminalitet och ökar den individuella lyckan. 
Med tanke på ovanstående finns det fog för att kalla de höga nivåerna av social tillit i Norden för ett nordiskt guld, både för individer och för samhället. Men det är inte en given naturresurs utan något som uppkommit under lång tid genom flera samverkande samhällsprocesser. De två aspekter som lyfts fram i texten handlar om statens roll samt föreningslivets funktion. Medan det senare förefaller haft en central funktion i ett tidigare historiskt skede som till stor del sammanföll med omvandlingen av de nordiska samhällena från agrara- till industrisamhällen, har det förra, alltså statens roll, spelat en särskilt viktig roll under de senare årtiondena.

Genom det frivilliga organisationsliv som uppstod under 1800-talet i Norden, ofta samlat inom begreppet folkrörelser och där föreningarna $i$ en internationell jämförelse påfallande ofta var frivilliga, lokalt förankrade och medlemsbaserade med ett centralt inslag av demokratiska beslutsprocesser, skapades ett slags sammanhållande kit i samhället i form av starka sociala normer om tillit och respekt. Dessa kom att sätta djupa spår i de nordiska samhällena.

Vad gäller statens roll har forskningen framför allt pekat på upplevd rättvisa i samhällsinstitutionernas agerande samt låg grad av korruption, särskilt under de senaste årtiondena. En annan viktig faktor är en generell välfärdsstat som motverkat skapandet av underklasser i samhället. Att staten också eftersträvat att höja utbildningsnivån i befolkningen har haft positiv betydelse i sammanhanget.

En särskilt gynnsam aspekt för den sociala tilliten i Norden har varit relationen mellan stat och organisationer. Föreningarna fyllde en viktig funktion som plattform för politiskt inflytande för den enskilde medborgaren vilket gett såväl ökad tillit till myndigheter och andra samhällsinstitutioner som i förlängningen ökad social tillit. Staten har samtidigt haft ett en öppen attityd till organisationerna, även om föreningarna i många fall haft ett kritiskt förhållningssätt till statlig politik.

En betydande del av det guld som Norden har i form av social tillit och som har haft en positiv effekt på bland annat ekonomin har kommit till samhällena genom att staten arbetat transparent, rättvist och med hög nivå av integritet och de positiva effekter detta medfört. När man ska se på de nordiska ländernas ekonomiska framgångar är detta en nyckelfaktor.

Tillit är på många sätt det kitt som får de nordiska samhällena att hålla samman. De nordiska samhällena har troligen mer att förlora på minskad social tillit än andra länder. Inte bara på grund av att de nordiska samhällena har det högsta tillitsnivåerna utan för att samhällsmodellen, eller snarare själva samhällskontraktet, bygger på hög social tillit. 
Trots att Norden är mindre unikt och homogent idag än tidigare ger det ändå mening att tala om en nordisk samhällsmodell.

Norden uppvisar högst tillit i hela världen.

Tillit utgör en del av det sociala kapitalet i samhället.

\section{Inledning}

Ekonomen Lars Calmfors har ägnat sig åt frågan vad som särskiljer Sverige, Norge, Danmark, Finland och Island från andra länder runt om i världen. Över tid, menar han, har det blivit allt svårare att hävda att de nordiska samhällena markant särskiljer sig från andra, i första hand europeiska länder. Ett flertal andra länder har också höga skattenivåer, generösa välfärdssystem med omfattande offentlig sektor och hög täckningsgrad av kollektivavtal på arbetsmarknaden med flera inslag som historiskt associerats med de nordiska länderna. Dessutom har de nordiska länderna blivit mer heterogena på områden där vi tidigare framstod som en enhet, exempelvis vad gäller skillnader i marginalskatter och den offentliga sektorns storlek i förhållande till BNP. Calmfors menar ändå att faktorer som bland annat jämlikhet i inkomstfördelning, höga sysselsättningsnivåer särskilt bland kvinnor och äldre, låg statsskuld, fokus på flexicurity på arbetsmarknaden, stora investeringar i humankapital och stor andel av befolkningen anställd inom offentlig sektor gör att det fortfarande är meningsfullt att tala om en nordisk samhällsmodell. Calmfors pekar dessutom särskilt på ett område där Norden i markant grad utmärker sig jämfört med andra länder. Det gäller tillit. Ingen annan region i världen når upp till de nordiska tillitsnivåerna. ${ }^{1}$

Denna text syftar till att lyfta fram tilliten, särskilt den sociala tilliten, i Norden: på vilket sätt särskiljer sig Norden från andra jämförbara länder, vilka effekter har tilliten för de nordiska samhällena, hur har den uppstått och vilka potentiella hot kan vi se mot tilliten i de nordiska samhällena? Det är meningen inte att ge en heltäckande bild över den aktuella forskningen på området utan snarare att skapa underlag för en diskussion. Denna text vill argumentera för att tillit kanske är den viktigaste resursen i de nordiska samhällena - ett nordiskt guld om man så vill - och att det är en central faktor för att förstå de nordiska ländernas moderna framgångar, både socialt och ekonomiskt. En poäng med denna text är också att tydliggöra att skapa och bevara tillit i samhället inte är omöjligt utan ligger i beslutsfattares händer.

\section{Tillitsbegreppet}

Tillit (från engelskans trust) har varit föremål för omfattande studier sedan omkring 1980-talet. Många av studierna har bedrivits av sociologer och ekonomer. Ofta brukar tillit ses som en delmängd av det sociala kapitalet $i$ ett samhälle. Enligt en av fältets mest kända forskare, Robert Putnam, ska socialt kapital ses som summan av normer, tillit och nätverk. ${ }^{2}$

Tillitsforskningen har historiskt legat vid sidan om den neoklassiska ekonomiska teoribildning då den bygger på en delvis annan beslutsrationalitet än den som präglat den neoklassiska forskningstraditionen. Man kan förstå att den kraftiga tillväxten av tillitsforskningen under senare år i viss mån är ett resultat av brister $\mathrm{i}$ förklaringsmodeller inom den neoklassiska traditionen.
1. L. Calmfors,"How well is the Nordic Model Doing? Recent Performance and Future Changes", in T. Valkonen \& V Vihriäla (eds.), The Nordic Model - Challenged but Capable of Reform (2014). Det ska påpekas att Island efter finanskrisen inte haft samma låga statsskuld som övriga nordiska länder.

2. R. Putnam, Making Democracy Work: Civic Traditions in Modern Italy (1993). 
Från neoklassiska håll har man, som ett svar på detta, nyanserat bilden av individers beslutsrationalitet och försöker numera inkorporera sådant som exempelvis tillit, normer och kultur. ${ }^{3}$

En individs tillit mot aktörer, institutioner och företeelser kan skifta. Exempelvis kan en individ ha en viss grad av tillit till politiker, en annan till myndigheter och ett tredje till en granne eller kollega. Ett vanligt förekommande sätt att i forskningssammanhang praktiskt hantera tillit är att specifikt se närmare på det som brukar benämnas social tillit (social trust). Med social tillit avses i vilken omfattning som människor litar på andra människor som de på förhand inte känner. ${ }^{4}$ Genom att lyfta fram uppmätta resultat av social tillit från individ- till samhällsnivå brukar forskare mena att man får möjlighet jämföra det sociala kapitalet mellan olika samhällen och geografiska områden.

Utifrån ovanstående kan man ana att den sociala tilliten kan betraktas som en individs uppfattning om människans natur. Social tillit handlar på många sätt om förväntan att en given norm respekteras av människor man inte känner och att dessa personer inte försöker lura dig. Med andra ord är social tillit ett mått på en individs uppfattning av den moraliska nivån i det samhälle som han eller hon bor i. ${ }^{5}$
Med social tillit avses i vilken utsträckning man litar på människor som man på förhand inte känner.

Social tillit kan ses som en enskild individs uppfattning av den moraliska nivån i samhället: kan man lita på andra människor? Detta kan sedan föras upp från individ- till samhällsnivå vilket ger möjlighet att jämföra nivån på det sociala kapitalet mellan olika samhällen.

\section{Välsignelser av tillit}

Det existerar relativ konsensus kring tillitens effekter. Dessa kan delas upp i ekonomiska- samt andra effekter. Nedanstående är bara några exempel på en rik och omfattande vetenskaplig litteratur som nästan enhälligt alla pekar åt samma håll: ett samhälle med hög nivå av social tillit har många fördelar, såväl för den enskilde som för samhället i dess helhet. De allra flesta av oss skulle utan tvekan föredra att leva i ett högtillitssamhälle än i ett som uppvisar låg grad av social tillit.

Samhällsekonomin gynnas på flera sätt om det finns en hög grad av social tillit. ${ }^{6}$ Det mest uppmärksammade är att samhället i minde grad präglas av formaliteter, konflikter och rättsprocesser. Man kan se tillit som frånvaro av behov att verifiera andra aktörers handlingar. ${ }^{7}$ Uttryckt i ekonomiska termer minskar social tillit transaktionskostnaderna i samhällsekonomin, alltså de kostnader som är förbundna med att se till att avtal efterlevs. Avsaknad av social tillit kräver omfattande kontroll genom myndigheter av formella och nedtecknade lagar. Det är tid som i sista ändan tas från produktivt arbetet.

3. Ett konkret sätt att inkorporera tillit i den neoklassiska traditionen är att betrakta den som en social norm som reducerar komplexitet i informationstillgången. Se D. Furlong, The Conceptualization of Trust in Economic Thought (1996).

4. Ibland kallas det även för generell tillit.

5. Mer om detta kan man läsa om i E.M. Uslaner, The Moral Fundation of Trust (2002).

6. Se exempelvis G. Tabellini, "Culture and Institutions: Economic Development in the Regions of Europe", in Journal of the European Economic Association 8 (2010). För en kritisk text, se F. Roth, "Does Too Much Trust Hamper Economic Growth?", in Kyklos. International Review for Social Science 62 (2009).

7. P.J. Zak \& S. Knack,"Trust and Growth", in The Economic Journal 111 (2001). En specialfall rör avsaknad av kontrollbehov i arbetslivet. Se A. Ilsøe, "Between Trust and Control: Company-level Bargaining on Flexible Working Hours in the Danish and German Metal Industries", in Industrial Relations Journal 41 (2010).

Hög nivå av social tillit minskar transaktionskostnaderna i ekonomin. Det finns också andra fördelaktiga ekonomiska effekter av höga nivåer av tillit. 
att social tillit förenklar samarbete och skapar altruistiska preferenser i befolkningen. ${ }^{12}$ Över lag är människor med hög grad av social tillit också mer benägna att uppfatta att de har större kontroll över sina liv och bättre livschanser. ${ }^{13}$ Tillit har också kommit att betraktas som en viktig beståndsdel i främjandet av politiskt engagemang och demokratisk utveckling i samhället i stort. ${ }^{14}$ Det har också påvisats ha en gynnsam (negativ) effekt på kriminalitet. ${ }^{15}$

En reflektion om den omfattande forskningslitteraturen på området är att det kan vara svårt att avgöra vad som skapar social tillit och vad som är en effekt av det. Exempelvis är det tänkbart och troligt att ekonomisk tillväxt i sig främjar den sociala tilliten i ett samhälle, vilket i sin tur gynnar fortsatt god tillväxt. ${ }^{16}$ Detsamma gäller också för nedbrytande cirklar, där sjunkande tillit påverkar faktorer som i sig ger negativa återverkningar på tilliten. Med andra ord, relationen mellan tillit och dess konsekvenser påminner om analysen av vem kom först: hönan eller ägget. I detta sammanhang är det tillräckligt att konstatera att närvaro av social tillit i ett samhälle har kapacitet att skapa positiva cirklar där tilliten och dess effekter korsvis förstärker varandra, eller - om man hamnar i en negativ spiral riskerar att ömsesidigt försvaga varandra.

\section{Den nordiska tilliten}

Det vanligaste sättet att mäta social tillit i Europa är de studier som bedrivs av European Social Survey. Studierna startade 2001 och har utförts vartannat år. Personer i respektive ingående land får ange på en tiogradig skala i vilken utsträckning de anser att de kan lita på flesta människor. Den senaste studien utfördes 2014. Enligt den så står Norden ut som de fyra toppländerna. Det har inte gått att finna några siffror för Island för 2014, men vid motsvarande studie 2012 ska de haft ett viktat medelvärde som sammanföll med Sveriges. ${ }^{17}$ (Vad som är särskilt intressant med Island är att efter finanskrisen steg, paradoxalt nog, den sociala tilliten i den isländska befolkningen) ${ }^{18}$

Hög social tillit är sammantaget ett nordiskt särdrag. Det ska inte ses som att andra länder saknar det men det är få som kommer i närheten av samma nivåer som de nordiska länderna. Det enda land som vid sidan av de nordiska fick en tillitsnivå över 6 är Nederländerna. Medelvärdet för de ingående länderna låg på strax över 5. Inom forskningen benämns Norden inom tillitssammanhang ibland under begreppet "Nordisk exceptionalism".19

12. Putnam (1993).

13. Se B. Rothstein, "Corruption and Social Trust: Why the Fish Rots from the Head Down", in Social Research 80 (2013). Se även A. Leung (et. al.), "Searching for Happiness: The Importance of Social Capital", in Journal of Happiness Studies 12 (2011).

14. R. Putnam, Bowling Alone. The Collapse and Revival of American Community (2000). Det finns också en diskurs som vill hävda att tillit under vissa betingelse kan gynna auktoritära styrene, se D. Acemoglu (et. al.), "Chiefs: Economic Development and Elite Control of Civil Society in Sierra Leone", in Journal of Political Economy 122 (2014).

15. B.P. Kennedy (et. al.), "Social Capital, Income Inequality and Firearm Violent Crime", in Social Science and Medicin 47 (1998)

16. C. Bjørnskov, "Economic Growth", in: G.L.H. Svendsen \& G.T. Svendsen (eds.), Handbook of Social Capital (2009).

17. R.F. Andersen \& P.T. Dinesen, "Social Capital in the Scandinavian Countries", Forthcoming in P. Nedergaard \& A. Wivel (eds.), Routledge Handbook on Scandinavian Politics.

18. K. Growiec (et. al.), "Social Capital and the Financial Crisis: The Case of Iceland", in CIES e-Working Papers138 (2012).

19. J. Delhey \& K. Newton, "Predicitng Cross-National Levels of Social Trust in Seven Societies: Global Pattern or Nordic Exceptionalism?" in European Sociological Review 29 (2013).
Enligt European Social Survey har de nordiska länderna högst nivåer av social tillit. 
Social tillit i de europeiska länderna utifrån European Social Survey 2014

Medan noll motsvarar ingen tillit alls utgör tio full tillit till andra människor.

\begin{tabular}{|l|l|l|l|}
\hline Land & Medelvärde & Belgien & 5,02 \\
\hline Danmark & 6,90 & Österrike & 4,98 \\
\hline Finland & 6,74 & Litauen & 4,94 \\
\hline Norge & 6,62 & Spanien & 4,83 \\
\hline Sverige & 6,25 & Frankerike & 4,61 \\
\hline Nederländerna & 6,03 & Tjeckien & 4,59 \\
\hline Schweiz & 5,72 & Ungern & 4,17 \\
\hline Estland & 5,57 & Slovenien & 4,07 \\
\hline Storbritannien & 5,37 & Polen & 3,92 \\
\hline Irland & 5,23 & Portugal & 3,63 \\
\hline Israel & 5,17 & & \\
\hline Tyskland & 5,17 & & \\
\hline
\end{tabular}

Social tillit i de europeiska länderna utifrån European Social Survey 2014. Medan noll motsvarar ingen tillit alls utgör tio full tillit till andra människor.

Det är värt att notera att distributionen av tillit inom de nordiska länderna inte är jämnt fördelad. Skillnaderna är något högre mellan regioner i Finland och Sverige jämfört med Norge och Danmark. Det vill säga att den sociala tilliten är (geografiskt) jämnare fördelad i Norge och Danmark jämfört med Sverige och Finland. Samtidigt är fördelningen inom Finland och Sverige mindre tydlig än situationen i övriga Europa, som uppvisar större geografiska spridning av tillitsnivåerna inom länderna. ${ }^{20}$

Bottennoteringar för tillit $i$ ett globalt perspektiv återfinns som regel i Mellanöstern, Afrika och delar av Latinamerika. ${ }^{21}$ Låga tillitsnivåer i fattiga länder blir i sig en hämsko för möjligheterna till utveckling.

\section{Tillit så in i Norden}

Det finns två övergripande förklaringsmodeller för uppkomsten av social tillit. Den ena betonar sociala förhållanden medan en andra lägger mer vikt på institutionella. De två modellerna står inte i motsats till varandra utan kan ses som komplementära.

Eftersom nivån på den sociala tilliten skiftar mellan olika samhällen och länder har det varit intressant för forskare att studera hur den uppstår. Det finns två ansatser för att förklara uppkomsten av social tillit; en förklaringsmodell betonar sociala förhållanden medan en andra lägger mer vikt på institutionella. Den första (som betonar sociala förhållanden) pekar specifikt på faktorer som berör sociala interaktioner i samhället, t ex i form av engagemang inom arbetsliv och civilsamhälle som viktigast för att långsiktigt bygga upp tilliten i samhället. Den andra (med större fokus på institutionella faktorer) lägger i stället mer tyngd på politiska och ekonomiska institutioner samt socioekonomiskt utfall.

20. P.T. Dinesen \& K.M. Sønderskov, "Trust in a Time of Increasing Diversity: On the Relationship between Ethnic Heterogenity and Social Trust in Denmark from 1979 until Today", in Scandinavian Political Studies 35 (2012).

21. B. Rothstein \& E.M. Uslaner, "All for All. Equality, Corruption and Social Trust", in World Politics 58 (2005). Se även H. Höjer, "Sveriges unika tillit sjunker: Kan man lita på folk?" i Forskning och Framsteg 8 (2014). 
Ansatserna behöver inte ses som uteslutande av varandra utan kan med fördel betraktas som komplementära.

Rasmus Fonnesbæck Andersen och Peter Thisted Dinesen vid Köpenhamns universitet visar, utifrån en genomgång av andra studier, att de nordiska samhällena sannolikt tidigt uppvisade höga nivåer av socialt kapital. Detta har man i andra studier försökt bekräfta genom att exempelvis studera svenskar som utvandrade till USA och som tog med sig tilliten: även efter flera generationer ger amerikaner med skandinavisk bakgrund uttryck för högre samhällelig tillit än andra amerikaner. ${ }^{22}$ Forskare har bland annat pekat på införandet av protestantismen i de nordiska länderna som en viktig förklaring bakom tidiga tillitsnivåer. Särskilt protestantismens icke-hierarkiska karaktär har man menat gett den sociala tilliten en möjlighet att utvecklas. ${ }^{23}$ Andra har velat gå så långt tillbaka som till vikingaperiodens tidiga statsbildningar och handelsnätverk som viktiga förklaringsfaktorer. ${ }^{24}$

Det är svårt att rent metodologiskt avgöra omfattningen på denna tidiga nordiska tillit. De nivåer vi kan mäta idag har ändå sannolikt bara lite att göra med den tillit vi kan finna historiskt. Det är också högst troligt att om man tar långa historiska perspektiv har tilliten i de nordiska samhällena varierat över tid, men har kommit att fördjupas i modern tid medan den i många andra länder utanför Norden snarare har minskat under samma period, särskilt under de senaste årtiondena. ${ }^{25}$ Den intressanta frågan gäller således hur den kommit att bli så hög i modern tid. Uttryckt mer exakt handlar det om hur de tidiga formerna av tillit i Norden kunna fördjupas i samband med de ländernas förvandling till moderna samhällen och dessutom ytterligare ökat under senare år.

Den (relativt) moderna historia om den nordiska tilliten tar sitt avstamp i samband med de stora folkrörelserna under andra hälften av 1800-talet. Folkrörelserna brukar vara den samlade benämningen av de folkliga massrörelserna som nykterhets-, väckelse- och arbetarrörelsen. Bildandet av dessa sammanföll till stor del med en genomgripande strukturomvandling av de nordiska samhällena. ${ }^{26}$ Till sin utformning och funktion kom de organisationer som uppstod ur folkrörelserna att få stor betydelse på organisationslivet i Norden. ${ }^{27}$ De nordiska organisationerna har, i en internationell jämförelse, påfallande ofta varit frivilliga, lokalt förankrade och medlemsbaserade med ett centralt inslag av demokratiska beslutsprocesser. Genom det frivilliga organisationslivet uppstod ett slags sammanhållande kitt i samhället i form av starka sociala normer om tillit och respekt som stöttar och underlättar samarbete. Denna viktiga aspekt fick en extra dimension i Norden utifrån strukturen på föreningarna.

En följd av den nordiska organisationstraditionen är att den bidragit till att skapa tillit mellan organisationer som i utgångsläget haft motstridiga intressen, men som genom förhandlingar byggt upp hög tillit till varandra. ${ }^{28}$

22. L. Trägårdh, "Den dumme svensken och allemansrättens magi", in L. Trägårdh (ed.), Tilliten i det moderna Sverige. Den dumme svensken och andra mysterier (2009).

23. För en diskussion om detta inklusive hänvisning till annan forskning se, C. Bjørnskov, "The Determinants of Trust", in Ratio Working Papers (2005).

24. G.L.H. Svendsen \& G.T. Svendsen, "How did Trade Norms Evolve in Scandinavia?: Long-Distance Trade and Social Trust in the Viking Age", in Economic Systems 40 (2016).

25. Se Andersen \& Dinesen (Forthcoming).

26. För en svensk diskussion om strukturomvandlingen under 1800-talet, folkrörelserna och relationen till tillit, se G. Svedin, "En ohyra på samhällskroppen": Kriminalitet, kontroll och modernisering i Sverige och Sundsvallsdistriktet under 1800- och det tidiga 1900-talet (2015).

27. B. Rothstein, "Social Capital in Scandinavia", in Scandinavian Political Studies 26 (2001).

28. A. Ilsøe, "The Flip Side of Organized Decentralization: Company-Level Bargaining in Denmark", in British Journal of Industrial Relations 50 (2012).
Även om Norden redan tidigt uppvisade höga nivåer av social tillit har nivåerna sannolikt varierat över tid i historien.

Den moderna historien om den sociala tilliten i Norden började med folkrörelserna under 1800-talet. Dessa var frivilliga, lokala och medlemsbaserade med demokratiska beslutsprocesser. Genom dessa uppstod grunden för ett sammanhållande kit i samhället i form av normer om tillit och respekt som också stöttar samarbete. 
Staten stöttade föreningarna - inte minst ekonomiskt. Över lag har staten haft en öppen attityd mot frivilligorganisationer.
Organisationerna utvecklade en viktig relation till staten. ${ }^{29}$ En bakgrund till detta är att redan tidigt i nordisk historia sågs staten, liksom lagstiftningen, av befolkningen inte som en fiende, på samma sätt som fallet varit i många andra länder. ${ }^{30}$ Det nordiska föreningslivet har också varit starkt subventionerat av skatteintänkter. Det har medfört att civilsamhället arbetat parallellt med staten även om det ofta - paradoxalt nog - varit en organisering i direkt kritik av staten eller av statlig politik. Medlemskap i en organisation och statens öppna förhållningssätt bidrog till att bilda förutsättningar för maktspridning. I sin tur bidrog detta till att öka den institutionella tilliten men även den mer generella sociala tilliten i samhället. ${ }^{31}$ Längst gick man sannolikt i Sverige där relationen kom så nära att det tidvis går att tala om att intresseorganisationerna sammanväxte med statsapparaten. ${ }^{32}$ Man kan till och med tala om ett korporativt samhälle där individen får en betydande andel av sitt politiska inflytande via medlemskapet i en intresseorganisation (snarare än att det sker via exempelvis proteströrelser).

Den stora samhälleliga betydelsen av folkrörelserna har minskat under senare årtionden då bland annat medlemskapet i organisationerna sjunkit. Å andra sidan har andra typer av föreningar ökat. Dessa återfinns inte minst inom sport och kultur men även inom miljö- och andra politiska områden. ${ }^{33}$ För resonemanget i denna text innebär det att föreningslivets samhälleliga roll minskat då den senare tidens föreningar inte är av samma typ som folkrörelsernas organisationer utan snarare bygger på ett passivt medlemskap och professionella kanslier. Det har minskat föreningslivets samlade betydelse för den sociala tilliten. Samtidigt har föreningslivet fortfarande en viktig funktion genom förmedlande av vissa normer som påverkar den långsiktiga tilliten i samhället.

Trots förändringen i organisationernas struktur har Sønderskov och Dinesen funnit remarkabla ökningar av den sociala tilliten i Sverige, Norge och Danmark sedan omkring 1980. Här, menar de, har faktorer som upplevd rättvisa i samhällsinstitutionernas agerande och låg grad av korruption varit av avgörande betydelse. ${ }^{34} \mathrm{Vid}$ sidan av den mer generella sociala tilliten uppvisar de nordiska länderna också hög grad av tillit - jämfört med andra europeiska länder - i relation till det juridiska systemet och politiker. ${ }^{35}$ Vad gäller korruption har många forskare pekat på att de nordiska länderna är de "renaste" i världen. ${ }^{36}$ I Transparency Internationals in-

29. Det har tidvis funnits en diskurs om huruvida det finns en motsättning mellan staten och civilsamhället. För en översikt av denna se L. Bennich-Björkman (et. al.), Civilsamhället, in Demokratiutredning VIII (1999).

30. L. Trägårdh, "The Historical Incubators of Trust in Sweden. From the Role of Blood to the Rule of Law", in M. Reuter (et. al.), Trust and Organizations: Confidence across Borders (2013). Se även Andersen \& Dinesen (Forthcoming) samt P. Selle, "The Transformation of the Voluntary Sector in Norway: A Decline in Social Capital?", in van Deth (et. al.), Social Capital and European Democracy (1999). Se också intervju med bland annat Trägårdh och Rothstein i Höjer (2014).

31. Detta knyter an till argumentationen i Andersen \& Dinesen (Forthcoming) liksom K.M. Sønderskov \& P.T. Dinesen, "Danish Exceptionalism: Explaining the Unique Increase in Social Trust in Denmark Over the Past 30 Years", in European Sociological Review 30 (2014). För en tidigare diskussion se B. Rothstein \& D. Stolle, "Introduction: Social Capital in Scandinavia", in Scandinavian Political Studies 26 (2003). För en övergripande diskussion om relationen mellan, å ena sidan, tillit och, å andra sidan, protest eller inkludering i samhällsinstitutioner, se J.F. Valencia (et. al.), "Social Trust and Political Protest: The mediating role of the value of Power Distance", in Psicología Política 40 (2010).

32. B. Rothstein, Den korporativa staten (1992).

33. Se exempelvis L. Torpe, "Foreningsdanmark", in P. Gundelach (ed.) Små og Store Forandringer. Danskernes Værdier siden 1981 (2011) och Rothstein (2001).

34. Sønderskov \& Dinesen (2014). I Danmark är det särskilt intressant, då man på några årtionden lyckats öka tilliten till att bli högst i världen.

35. Calmfors (2014).

36. S. Holmberg \& B. Rothstein (eds.), Good Government: The Relevance of Political Science (2012). 


\begin{tabular}{|l|l|l|}
\hline Placering & Land & 90 \\
\hline 1 & Danmark & 90 \\
\hline 2 & Nya Zeeland & 89 \\
\hline 3 & Finland & 88 \\
\hline 4 & Sverige & 86 \\
\hline 5 & Schweiz & 85 \\
\hline 6 & Norge & 84 \\
\hline 7 & Singapore & 83 \\
\hline 8 & Nederländerna & 82 \\
\hline 9 & Canada & 81 \\
\hline 10 & Tyskland & 81 \\
\hline 10 & Storbritanien & 81 \\
\hline 10 & Luxemburg & 8 \\
\hline
\end{tabular}

dex över uppfattad korruption i 176 olika länder och territorier runt om i världen bekräftas detta. Bland de topp tio placerade länderna återfinns fyra av de nordiska med Island på 14.e plats med ett index-tal på 78.

Staten har även andra potentiella funktioner i relation till tilliten i samhället. Vid sidan om faktorer som upplevd rättvisa och låg grad av korruption har forskning även pekat på att samhällen med generell välfärdsstat tenderar att nå höga tillitsnivåer. ${ }^{37}$ Den nordiska välfärdsstaten tenderar att undvika att skapa den typ av underklass som man kan finna i länder med anglosaxiska eller kontinentala välfärdsmodeller, där bistånd är striktare villkorat och selekterat utifrån behov. ${ }^{38}$

Detta för vidare till ett i forskningen ofta konstaterat faktum, nämligen att hög grad av homogenitet i en befolkning stärker den sociala tilliten. Det gäller främst avseende inkomstjämlikhet, men i viss utsträckning även språklig och etnisk likhet. Att social tillit och ekonomiska klyftor samvarierar verkar främst kunna förklaras av en upplevd orättvisa, där större skillnader gör att människor inte uppfattar att de delar "samma öde". Francis Fukuyama talar i en klassisk studie om en tillitsradie: ju mer lika andra är en själv, desto mer tenderar man att lita på dem. ${ }^{39}$ När det gäller den ekonomiska jämlikheten i relation till social tillit brukar man särskilt lyfta fram avsaknad av en permanent underklass i samhället, men även att välbeställdas löner inte uppfattas som allt för orättvisa. ${ }^{40}$

Andra gynnsamma faktorer för den sociala tillitens tillväxt i Norden under de senaste årtiondena är en stigande utbildningsnivå i befolkningen, ${ }^{41}$ samt frånvaro av hög, långvarig arbetslöshet. ${ }^{42}$

37. B. Rothstein, "Corruption, Happiness, Social Trust and the Welfare State: A Causal Mechanisms Approach", in QoG Working Paper Series 9 (2010).

38. Rothstein \& Stolle (2003)

39. Fukuyama (1995).

40. Se bland annat J. You, "Social Trust: Fairness Matters More than Homogenity", in Political Psychology 33 (2012).

41. S. Knack \& P.J. Zak, "Building Trust: Public Policy, Interpersonal Trust, and Economic Development", in Supreme Court Economic Review 10 (2002).

42. Uslaner (2002). 


\section{Utmaningar för den nordiska tilliten}

Om den sociala tilliten i samhället minskar blir det svårare att upprätthålla gemensamma normer. Individen blir också mindre benägen att bidra till det gemensamma. Social tillit är svårt att bygga upp men kan sannolikt erodera på ganska kort tid.
Trots att den nordiska tilliten skapats under många årtionden eller till och med århundraden genom olika historiska processer är den inte en resurs som kan tas för given. I dagsläget står den nordiska tilliten för ett flertal utmaningar.

Låt oss inledningsvis fokusera på vad ett samhälle står att förlora om den sociala tilliten minskar. På en mer principiell nivå handlar det om att aktörer uppfattar att andra invånare agerar som "fripassagerare", vilket gör det svårare att upprätthålla gemensamma normer, liksom att individen blir mindre benägen att bidra till det gemensamma. Bo Rothstein, professor vid Göteborgs universitet, har kallat detta förhållande för den sociala fällans logik. ${ }^{43}$ Han exemplifierar vad som riskerar att ske om den sociala tilliten minskar. Rothstein menar att det minskar det meningsfulla för den enskilde att betala skatt, inte missbruka försäkringssystemen, sortera av avfall, följa lagstiftning, inte acceptera korruption.

På många sätt handlar effekterna av minskad social tillit om motsatsen till de långsiktiga välsignelser som lyfts fram tidigare i texten. I korta ordalag skapar det försämrad samhällsekonomi, mindre lyckliga medborgare, sämre fungerande samhällen med risk för ökad kriminalitet och ökande svårigheter att upprätthålla delar av det demokratiska fundamentet.

Det kanske skadligaste i sammanhanget är att aktörer som förlorat tillit tillvarandra har svårt att återskapa den även om de är medvetna om att alla skulle vinna på ökat samarbete. ${ }^{44}$

Vilka specifika utmaningar står så de nordiska samhällena inför? Några av dem kan sammankopplas med ökande heterogenitet i de nordiska samhällena genom exempelvis ökad ekonomisk olikhet, invandring, ${ }^{45}$ samt politisk polarisering. ${ }^{46}$

En helt annan utmaning är korruption. Det är sant att Norden i ett globalt perspektiv kännetecknas av låg grad av korruption. Men om tilliten i de nordiska samhällena under senare år till stor del fördjupats genom låg korruption i myndighetsutövning kan orsakssambanden också lätt tippa åt andra hållet; begränsade ökningar av korruption kan få betydande negativa återverkningar på den sociala tilliten. ${ }^{47}$ Man kan uttrycka det som att ju fler personer vi tror är korrupta desto större blir sannolikheten att de är korrupta.

Som påpekats i avsnittet har ökningen av tilliten i Norden mycket att göra med den upplevda rättvisa som omgärdar samhällsinstitutionernas agerande. Den upplevda rättvisan kan minska, inte enbart som ett resultat av ökad korruption utan
43. B. Rothstein, Sociala fällor och tillitens problem (2003). Se även Rothstein (2013).

44. Rothstein (2013).

45. För en generell diskussion om detta se R. Putnam, "E Pluribus Unum: Diversity and Community in the Twenty-First Century", in Scandinavian Political Studies 30 (2007). Effekten av ökad invandring är inte så tydlig på aggregerad nivå utan återfinns snarare i lokalsamhället där den sociala tilliten är känsligare. L. Trägårdh et. al, Den svala svenska tilliten (2013). Se även NOU 2017:2, Integrasjon og tillit. Langsiktige konsekvenser av høy innvandring (2017).

46. L. Mason,"I Disrespectfully Agree: The Differential Effects of Partisan Sorting on Social and Issue Polarization". In American Journal of Political Science 59 (2014). Se även C. Rapp, "Moral Opinion Polarization and the Erosion of Trust", in Social Science Research 58 (2016).

47. P. Bardhan, "Corruption and Development: A Review of the Issues", in Journal of Economic Literature 35 (1997). 
sannolikt också på grund av att fattade beslut inte ses som legitima, exempelvis om offentlig verksamhet inte använder skattemedel på ett förnuftigt sätt.

Om de nordiska länderna skulle drabbas av hög och långvarig arbetslöshet finns det risk för att detta kan påverka den sociala tilliten. Detta hör till stor del samman med den tidigare diskuterade utmaningen med eventuell ökad ekonomisk olikhet i samhället.

Det nordiska föreningslivets historiska centrala betydelse för den sociala tilliten har understrukits i framställningen. Det är utanför syftet för denna text att undersöka i vilken utsträckning föreningslivet i Norden har sjunkit under senaste år, eller i vilken utsträckning det är hotat. Men om föreningslivet står inför en nedgång är det inte bara en förlust för föreningslivet som sådant utan även något som kan ha en negativ påverkan på den långsiktiga tillitsnivån i samhället.

Ovan har några av de utmaningar som den nordiska tilliten står inför lyfts fram. Dessa utmaningar är viktiga att ta på allvar. Samtidigt är det viktigt att ha en balanserad syn. De flesta utmaningarna är inte nya utan har existerat under de senaste årtiondena. Trots det har den sociala tilliten över lag fortsatt att stiga $\mathrm{i}$ de nordiska samhällena.
En ökning av korruption skulle kunna ha destruktiv effekt på den sociala tilliten. Andra utmaningar hör på olika sätt samman med ökad heterogenitet inom den nordiska befolkningen. En tredje utmaning är risken för långvarig arbetslöshet

Även om utmaningarna för den sociala tilliten måste tas på allvar är det viktigt att ha en balanserad syn. Många av utmaningarna är inte nya. Trots det har den sociala tilliten i Norden ökat. 




\section{Konklusioner}

I de nordiska länderna är den sociala tilliten exceptionellt hög i jämförelse med nästan alla andra länder. Det går med fog, vilket en del forskare gjort, att tala om en "nordisk exceptionalism".

Social tillit är en resurs för både individ och samhälle. I texten har flera sådana effekter lyfts fram. Sammantaget är det en stor välsignelse; i bildlig mening ett guld för ett samhälle, att ha omfattande social tillit i befolkningen.

Även om tillit är en viktig resurs för de nordiska samhällena är det ingen given naturresurs på samma sätt som guld (eller skog eller olja etc.). Det är inte något som har getts till de nordiska samhällena av naturen eller en gudomlig kraft, utan något som skapats under en längre period och genom olika samverkande processer. Historien om den nordiska tilliten tar troligen sin början långt bak i tiden, kanske redan under vikingatiden. Införandet av protestantismen och nedbrytandet av sociala hierarkier som följde med införandet var också betydelsefullt. Det var dock 1800-talets folkrörelser som - inte omedelbart men på sikt - gav tilliten en knuff framåt. Det skedde framförallt genom att folkrörelserna etablerade organisationer på gräsrotsnivå som var lokalt förankrade, demokratiskt styrda och medlemsbaserade. De nordiska organisationerna fick med tiden ett nära förhållande till staten som ekonomiskt och på andra sätt stöttade föreningslivet. En annan viktig aspekt, särskilt under de senaste årtiondena, har varit rätt- 
visa samhällsinstitutioner fria från korruption och en universell välfärdsstat som eftersträvat att motverka skapandet av en underklass. Höjd utbildningsnivå, låg arbetslöshet och en homogen befolkning - särskilt i ekonomisk mening - är andra områden där statlig politik gett positiva bidrag.

En delkonklusion utifrån ovanstående är att om man vill titta närmare på Nordens framgångar, särskilt i ekonomisk mening och ännu mer specifikt hur de nordiska länderna lyckats undvika den recession som drabbade världen efter finanskrisen 2008, ska man inte fokusera allt för mycket på hur man i Norden balanserat olika system, skatter, lagstiftning etc., utan istället se närmare på hur staten under lång tid arbetat transparent, rättvist och med hög nivå av integritet och de positiva effekter detta medfört - inte minst med avseende på social tillit.

Utifrån den genomgångna forskningen om de nordiska erfarenheterna kan man sammanställa en slags manual på hur staten kan agera för att långsiktigt öka den sociala tilliten:

- Agera med öppenhet och transparens, hantera skattemedel med respekt och bekämpa alla tecken på korruption, hur obetydliga de än kan förefalla.

- Skapa en generell välfärdsstat som motverkar formering av underklasser i samhället.

- Stötta föreningslivet, inte minst ekonomiskt. Det är generellt gynnsamt om staten kan ha en öppen attityd till föreningslivet.

- Höj utbildningsnivån i befolkningen. Utifrån vikten av att behålla en relativ ekonomisk homogenitet i befolkningen är det sannolikt särskilt viktigt att satsa på dem med (risk för) låg och/eller ofullständig utbildning.

- Motverka uppkomst av arbetslöshet, i synnerhet långtidsarbetslöshet. Detta sätter särskilt fingret på effektiv integration av flyktingar och invandrare på arbetsmarknaden.

Det förda resonemanget medför avslutningsvis att det är tillit som på många sätt får de nordiska samhällena att hålla samman. Det är svårt att föreställa sig samhällsmodeller som de nordiska om inte medborgarna litar på att andra medborgare också, genom skattesystemet, bidrar till samhällsekonomin samt att myndigheterna hanterar medlen på ett rättvist och effektivt sätt fritt från korruption. Frågan är om inte de nordiska samhällena har mer att förlora på minskad social tillit jämfört med andra länder. Inte enbart för att de nordiska samhällena har de högsta tillitsnivåerna i världen utan för att samhällsmodellen, eller snarare själva samhällskontraktet, till stor del bygger på social tillit. 


\section{Referenser}

Acemoglu, D. (et. al.), "Chiefs: Economic Development and Elite Control of Civil Society in Sierra Leone", in Journal of Political Economy 122 (2014)

Andersen, R.F. \& P.T. Dinesen, "Social Capital in the Scandinavian Countries", Forthcoming in P. Nedergaard \& A. Wivel (eds.), Routledge Handbook on Scandinavian Politics.

P. Bardhan, "Corruption and Development: A Review of the Issues", in Journal of Economic Literature 35 (1997)

Bennich-Björkman, L. (et. al.), Civilsamhället, in Demokratiutredning VIII (1999)

Bjørnskov, C., "The Determinants of Trust", in Ratio Working Papers (2005)

Bjørnskov, C., "Economic Growth", in: G.L.H. Svendsen \& G.T. Svendsen (eds.), Handbook of Social Capital (2009)

Blanchard, O. (et. al.), Unemployment, Labour-Market Flexibility and IMF Advice: Moving Beyond Mantras (2013)

Calmfors, L., "How well is the Nordic Model Doing? Recent Performance and Future Changes", in T. Valkonen \& V Vihriäla (eds.), The Nordic Model - Challenged but Capable of Reform, (2014).

De Groot, H.L.F (et. al.), "The Institutional Determants of Bilateral Trade Patterns", in Kyklos. International Review for Social Science 57 (2004)

Delhey, J. \& K. Newton, "Predicitng Cross-National Levels of Social Trust in Seven Societies: Global Pattern or Nordic Exceptionalism?" In European Sociological Review 29 (2013)

Dinesen, P.T. \& K.M. Sønderskov, "Trust in a Time of Increasing Diversity: On the Relationship between Ethnic Heterogenity and Social Trust in Denmark from 1979 until Today", in Scandinavian Political Studies 35 (2012)
Fukuyama, F., Trust: The Social Virtues and the Creation of Prosperity (1995)

Furlong, D., The Conceptualization of Trust in Economic Thought (1996)

Growiec, K. (et. al.), "Social Capital and the Financial Crisis: The Case of Iceland", in CIES e-Working Papers 138 (2012).

Holmberg, S. \& B. Rothstein (eds.), Good Government: The Relevance of Political Science (2012)

Höjer, H. "Sveriges unika tillit sjunker: Kan man lita på folk?" i Forskning och Framsteg 8 (2014)

Ilsøe, A.,"Between Trust and Control: Company-level Bargaining on Flexible Working Hours in the Danish and German Metal Industries", in Industrial Relations Journal 41 (2010)

Ilsøe, A., "The Flip Side of Organized Decentralization: Company-Level Bargaining in Denmark", in British Journal of Industrial Relations 50 (2012)

Kennedy, B.P. (et. al.), "Social Capital, Income Inequality and Firearm Violent Crime", in Social Science and Medicin 47 (1998)

Knack, S. \& P.J. Zak, "Building Trust: Public Policy, Interpersonal Trust, and Economic Development", in Supreme Court Economic Review 10 (2002)

Leung, A. (et. al.), "Searching for Happiness: The Importance of Social Capital", in Journal of Happiness Studies 12 (2011)

Mason, L., "I Disrespectfully Agree: The Differential Effects of Partisan Sorting on Social and Issue Polarization". In American Journal of Political Science 59 (2014)

NOU 2017:2, Integrasjon og tillit. Langsiktige konsekvenser av høy innvandring (2017) Putnam, R., Making Democracy Work: Civic Traditions in Modern Italy (1993) 
Putnam, R., Bowling Alone. The Collapse and Revival of American Community (2000)

Putnam, R., "E Pluribus Unum: Diversity and Community in the Twenty-First Century", in Scandinavian Political Studies 30 (2007)

Rapp, C., "Moral Opinion Polarization and the Erosion of Trust", in Social Science Research 58 (2016)

Rodríguez-Pose, A. \& V. von Berlepsch, Social Capital and Individual Happiness in Europe, in Bruges European Economic Research Papers 25 (2012) Roth, F., "Does Too Much Trust Hamper Economic Growth?", in Kyklos. International Review for Social Science 62 (2009)

Rothstein, B., Den korporativa staten (1992)

Rothstein, B., "Social Capital in Scandinavia", in Scandinavian Political Studies 26 (2001)

Rothstein, B., Sociala fällor och tillitens problem (2003)

Rothstein, B., "Corruption, Happiness, Social Trust and the Welfare State: A Causal Mechanisms Approach", in QoG Working Paper Series 9 (2010)

Rothstein, B., "Corruption and Social Trust: Why the Fish Rots from the Head Down", in Social Research 80 (2013)

Rothstein, B. \& D. Stolle, "Introduction: Social Capital in Scandinavia", in Scandinavian Political Studies 26 (2003)

Rothstein, B. \& E.M. Uslaner, "All for All. Equality, Corruption and Social Trust", in World Politics 58 (2005)

Selle, P., "The Transformation of the Voluntary Sector in Norway: A Decline in Social Capital?", in van Deth (et. al.), Social Capital and European Democracy (1999)
Svedin, G., "En ohyra på samhällskroppen": Kriminalitet, kontroll och modernisering i Sverige och Sundsvallsdistriktet under 1800- och det tidiga 1900-talet (2015)

Svendsen, G.L.H. \& G.T. Svendsen, "How did Trade Norms Evolve in Scandinavia?: Long-Distance Trade and Social Trust in the Viking Age", in Economic Systems 40 (2016)

Sønderskov, K.M. \& P.T. Dinesen, "Danish Exceptionalism: Explaining the Unique Increase in Social Trust in Denmark Over the Past 30 Years", in European Sociological Review 30 (2014)

Tabellini, G., "Culture and Institutions: Economic Development in the Regions of Europe", in Journal of the European Economic Association 8 (2010)

Torpe, L., "Foreningsdanmark", in P. Gundelach (ed.) Små og Store Forandringer. Danskernes Værdier siden 1981 (2011)

Trägårdh, L., "Den dumme svensken och allemansrättens magi", in L. Trägårdh (ed.), Tilliten i det moderna Sverige. Den dumme svensken och andra mysterier (2009)

Trägårdh, L., "The Historical Incubators of Trust in Sweden. From the Role of Blood to the Rule of Law", in M. Reuter (et. al.), Trust and Organizations: Confidence across Borders (2013)

Trägårdh L., et. al, Den svala svenska tilliten (2013)

Uslaner, E.M., The Moral Fundation of Trust (2002)

Valencia J.F. (et. al.), "Social Trust and Political Protest: The mediating role of the value of Power Distance", in Psicología Política 40 (2010)

You, J., "Social Trust: Fairness Matters More than Homogenity", in Political Psychology 33 (2012)

Zak, P.J. \& S. Knack,"Trust and Growth", in The Economic Journal 111 (2001) 


\section{Nordiska ministerrådet}

Ved Stranden 18

DK-1061 København K

www.norden.org

ANP 2017:731

ISBN 978-92-893-5003-7 (PRINT)

ISBN 978-92-893-5004-4 (PDF)

ISBN 978-92-893-5005-1 (EPUB) 